\title{
Water and nitrogen effects on growth and allocation pat- terns of creosotebush in the northern Chihuahuan Desert
}

\author{
F.M. FISHER, J.C. ZAK, G.L. CUNNINGHAM, AND W.G. WHITFORD
}

\section{Abstract}

A field experiment using 2 patterns of irrization and 1 level of nitrogen fertilizer $\left(10 \mathrm{~g}-\mathrm{N} \mathrm{m}^{-2}\right)$ was conducted in order to discern water and nitrogen interactions that may control production of creosotebush, (Larrea tridentata (D.C.) Cov. The 2 patterns of irrigation simulated precipitation from small, frequent events (6 mm water added weekly) or large, infrequent events ( $25 \mathrm{~mm}$ water added monthly). Understanding the factors controlling the production of this rangeland shrub may aid in the development of strategies for its management.

Vegetative growth occurred mostly during March-May (spring) and August-October (summer-fall). Fruit production occurred mainly in the spring and root growth occurred mainly in the summer-fall. Irrigation increased vegetative growth and decreased fruit production. Responses to irrigation were greater during summer-fall than in the spring. Small, frequent water additions caused larger increases in vegetative plus fruit growth than did large, infrequent water additions. Nitrogen fertilization increased the growth of both vegetation and fruit in irrigated and unirrigated plots. Stem mortality and root growth were not significantly affected by irrigation or nitrogen fertilizer. These results suggest that creosotebush production is limited by both soil moisture and nitrogen availability and that temporal patterns of rainfall may be as important as total amounts.

Key Words: Larrea tridentata, apical stem growth, reproductive allocation, stem mortality, root growth, simulated rainfall, nitrogen fertilizer

The increasing dominance of creosotebush (Larrea tridentata [D.C.] Cov.) in desert rangelands of the southwestern U.S. is well documented (Buffington and Herbel 1965, York and Dick-Peddie 1969). The invasion of creosotebush into grasslands is accompanied by increased erosion and reduced production of perennial grasses, and efforts to restore grass production have met with little success (Cox et al. 1984). An improved understanding of the factors limiting the production of creosotebush may aid in the development of management strategies for desert rangelands.

Plant production in deserts is thought to be largely limited by water, with most growth occurring in pulses associated with infrequent and highly variable precipitation (Noy-Meir 1973). However, a direct relationship between precipitation and plant production is frequently not observed (Charley 1972, Webb et al. 1978, Ludwig and Flavill 1979). Charley (1972) and Ludwig and Flavill (1979) reported reduced productivity in the second of 2 consecutive wet years. Charley (1972) attributed this to depletion of available nutrients, particularly nitrogen $(\mathbf{N})$. Other explanations for varying responses to precipitation are that the effects of moisture inputs may be modified by the timing, duration, and intensity of precipitation events, or that total plant production responses may be

Fisher, Cunningham, and Whitford are college assistant professor, professor, and professor, Dept. of Biology, New Mexico State University, Las Cruces 88003 . Zak is assistant professor, Dept. of Biology, Texas Tech University, Lubbock.

L.W. Parker, W.P. MacKay, and J.P. Anderson were instrumental in setting up and conducting this experiment. G.M. Southward of the New Mexico State University Dept. of Experimental Statistics provided valuable advice about the statistical analy. sis. R. Hunter, K. Killingbeck, K. Lajtha, and W. Schlesinger read and commented on this manuscript. This research was supported by National Science Foundation grant BSR 821539 to W.G. Whitford and by the Jornada Long Term Ecological Research Program (National Science Foundation grant BSR 814466).

Manuscript accepted 16 May 1988. masked by changes in biomass allocation patterns.

Besides water, $\mathbf{N}$ is generally considered to be the factor most limiting to desert plant growth (Charley 1972, West and Skujins 1978). Floret et al. (1982) suggested that $\mathrm{N}$ is an important limiting factor in the northern portion of the Sahara and Penning de Vries and Djiteye (1982) found that primary production varied with $N$ availability over a wide range of precipitation in the sub-Saharan Sahel. Charley (1972), Ettershank et al. (1978), and James and Jurinak (1978) reported significant responses of arid vegetation to $\mathbf{N}$ fertilizer without additional water.

The seasonal timing and pattern of moisture availability has been shown by the field experiments of Cunningham et al. (1979) to be an important factor influencing creosotebush growth. Ludwig and Flavill (1979) examined above-ground production of creosotebush in the northern Chihuahuan Desert over a 5-year period and suggested that small, frequent precipitation events were more effective than large, infrequent events delivering the same amount of moisture. This seems anomalous for a deep-rooted shrub, particularly since water from small events may be mostly lost through evaporation. However, if small, frequent events stimulate $\mathbf{N}$ mineralization thereby enhancing $\mathbf{N}$ availability, increased production could result (Fisher et al. 1987).

Despite the large body of data on factors affecting productivity of desert vegetation, we are aware of no studies assessing the interactions of these factors. Therefore, we designed a factorial study to examine the effects of small and large rain events and available soil $\mathbf{N}$ on growth and biomass allocation of creosotebush (Larrea tridentata [D.C.] Cov.). We hypothesized that small, frequent events would result in higher productivity than large, infrequent events. Further, based on forest studies (Waring and Schlesinger 1985), we hypothesized that increasing available $\mathbf{N}$ by fertilization would increase productivity of irrigated plants more than unirrigated plants. We also hypothesized that below-ground biomass allocation would decrease with irrigation and fertilization.

Reproduction may account for $50 \%$ or more of total aboveground production of creosotebush. Previous studies suggested that reproductive allocation was inversely related to moisture availability (Oechel et al. 1972, Cunningham et al. 1979). It is therefore necessary to measure reproductive allocation in order to understand the responses of creosotebush to various moisture and $\mathbf{N}$ additions.

\section{Materials and Methods}

\section{Study Site}

The study was conducted on the Jornada Long-Term Ecological Research (LTER) site located $40 \mathrm{~km}$ NNE of Las Cruces, New Mexico, at the New Mexico State University College Ranch. The LTER site, located on a northeast facing piedmont slope, traverses 7 vegetation types along a topographic gradient ranging from a rocky mountain side to an ephemeral lake bed. The creosotebushdominated vegetation in which the study was conducted is located approximately mid-slope ( $3 \%$ gradient) in loamy sand soils with a calcium carbonate deposition layer (caliche) at a depth of about 40 $\mathrm{cm}$. The soil is classified as a Typic Haplargid of the Dona Ana series. Additional soil characteristics are reported by Fisher et al. (1987). Annual precipitation averages $213 \mathrm{~mm}, 55 \%$ falling during July-September as convectional thundershowers. Average daily 
maximum temperature in June, the hottest month, is $36^{\circ} \mathrm{C}$, and the average daily minimum temperature in January, the coldest month, is $-3.3^{\circ} \mathrm{C}$.

\section{Experimental Procedures}

Three irrigation treatments (control, $6.3 \mathrm{~mm}$ water added weekly, $25.4 \mathrm{~mm}$ water added monthly) were assigned in a completely random design to 9 experimental plots $(5 \times 10 \mathrm{~m})$. Plots were fenced to prevent herbivory by rabbits and were irrigated from June, 1981, until March, 1985, except after precipitation events $>25 \mathrm{~mm}$. Fertilizer $\left(\mathrm{NH}_{4} \mathrm{NO}_{3}\right)$ was applied $\left(10 \mathrm{~g}-\mathrm{N} \mathrm{m}^{-2}\right)$ to the down-slope half of each plot (to prevent run-off of added $\mathbf{N}$ onto the unfertilized half) on 23 February 1983 and 19 June 1984. All plots were lightly watered to move the granular fertilizer into the soil.

Plots were irrigated with water from a stock tank located at the headquarters of the New Mexico State University College Ranch. Average total $\mathbf{N}$ content of the water from occasional analyses was $0.21 \mathrm{mg} 1^{-1}$, which is within the range of natural precipitation. Sodium concentrations were negligible. Concentrations of calcium $\left(\mathrm{Ca}^{++}\right)$, magnesium $\left(\mathrm{Mg}^{++}\right)$, and sulfate SO4-) were somewhat higher than typical precipitation. Water was pumped from a tank trailer through sprinkler fittings raised to a height of $1.5 \mathrm{~m}$. The irrigation spray descended upon the creosotebush shrubs from above, producing throughfall and stemflow patterns similar to those of an actual precipitation event. The irrigation volume was calibrated by placing containers inside of each of the study plots.

Ten apical stems were randomly selected on each of 5 shrubs per plot, tagged with yarn, and marked at $\mathbf{4 0} \mathrm{mm}$ from the tip with enamel paint. Beginning April, 1983, the length of all marked stems and the numbers of buds, flowers, and fruits were recorded at approximately 3-week intervals until November, 1983. All marked stems were harvested on January 1984 and oven dried at $50^{\circ} \mathrm{C}$ for determination of dry mass.

In February, 1984, new apical stems were selected and tagged using the same procedures as before. Stem length was measured monthly from March, 1984, until March, 1985. Counts of buds, flowers, and fruits were made every 2 weeks until November, 1984, and monthly thereafter. In this series of measurements, we attempted to distinguish stems suffering natural mortality from those dying or disappearing from disturbance during research activities. Dying stems were recognizable by the loss of leaves and lack of growth occurring over several measurement intervals. Mature fruits were collected from tagged shrubs on each plot to estimate the dry mass of individual fruits in November, 1984

Root growth was examined in root tubes comprised of a fiberglass mesh cylindrical bag supported by a slotted PVC plastic pipe $60-\mathrm{cm}$ long, 6-cm internal diameter. Three $2.5 \times 50-\mathrm{cm}$ slots were cut in each tube. Soil for the root tubes was obtained adjacent to the study site from a depth of $0-60 \mathrm{~cm}$, mixed, and sieved through a $2-\mathrm{mm}$ mesh to remove larger roots. The mesh bags were filled with sieved soil and placed in the slotted pipes. Fifteen root tubes were installed at the edges of creosotebush canopies to a depth of $60 \mathrm{~cm}$ in 6 of the 18 plots ( 15 tubes in each of the treatment combinations) in March 1984. Five tubes per plot were removed and replaced with fresh tubes in June, 1984, and August, 1984, and all 15 tubes were removed in October, 1984. Larger roots were removed manually. Fine roots and other light materials were collected by floating on $\mathrm{CHCl}_{3}$. Non-root light material was removed by hand from the floated fraction prior to ashing at $400^{\circ} \mathrm{C}$ for $24 \mathrm{~h}$. Estimated root biomass $<2 \mathrm{~mm}$ diameter initially present in the tubes was subtracted from the root biomass found in the retrieved tubes.

\section{Calculations and Statistical Analyses}

Initial statistical analyses were performed on the mean of stem lengths or of counts of fruits, buds, and flowers for each shrub. For the first year's data, missing or dead stems were excluded from calculations. For the second year, shrub means were calculated in the same way but stem mortality was calculated as lost stem length.
The stem length measurements were converted to stem + foliage (vegetative) mass estimates using regression equations. Significant differences between the biomass regression lines for different treatments were indicated by Analysis of Covariance (Freund and Littell 1981).

Fruit mass per apical stem was calculated as the number of fruits per branch times the mean fruit mass estimated from fruit harvests. Seasonal mass increments of fruits and vegetation were then calculated by dividing the year at July 1 to reflect the 2 periods of creosotebush growth in the Chihuahuan Desert (Cunningham et al. 1979). Total mass increment of the apical stems was calculated by adding the vegetative mass estimates from the regressions to the fruit mass estimates. Finally, reproductive allocation was calculated as the fruit mass increment divided by the sum of vegetative+ fruit mass increments.

Initial analysis of variance (ANOVA) indicated that the error term associated with the irrigation treatments was similar in magnitude to that of the $\mathrm{N}$ fertilizer treatments $(P>0.25)$, so the error terms were combined for subsequent analyses (G.M. Southward, personal communication). Stem lengths and fruit counts from each sampling date were analyzed separately to reduce problems with heterogenous variances. Orthogonal contrasts and Tukey's HSD test were used to indicate significant differences $(P<0.05)$ between treatments (Steel and Torrie 1980).

A second stage of the analysis was conducted in order to simplify the interpretation of the water/ $\mathbf{N}$ interactions. Since the error associated with the water and nitrogen plots had been pooled, it was possible to reanalyze the stem increment data and the reproductive allocation data using a one-way ANOVA. Significance tests used (Tukey's HSD, Dunnett's $t$ ) were appropriate for $a$

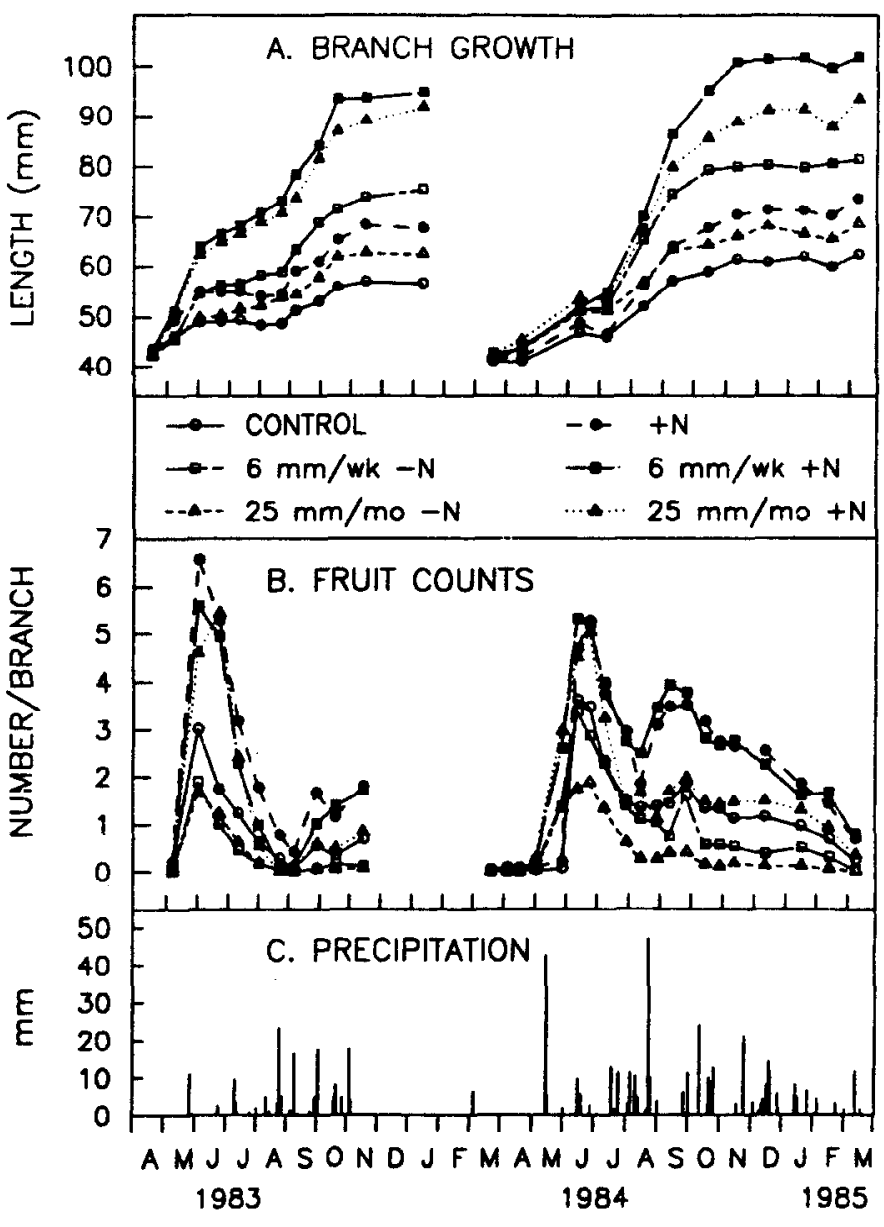

Fig. 1. Effects of nitrogen fertilization and 2 patterns of irrigation on the length and number of fruits on tagged creosotebush branches. Values are means of 3 plots. Precipitation recorded at the study site is also shown. 
posteriori comparisons (Steel and Torrie 1980). Significant differences $(P<0.05)$ between treatments were indicated by Tukey's HSD test and significant differences of all water and nitrogen treatments vs. the unwatered unirrigated controls were indicated by Dunnett's test.

Residuals from all analyses were plotted against predicted values and tested for normality using the Kolmogorov D statistic. Log transformations were used to homogenize the variance of fruit counts and the mass increment data.

\section{Results}

Stem growth occurred mostly during March-May (spring) and August-October (late summer-fall) with the latter period being more important (Fig. 1). Fruit production occurred mainly in the spring. Stem growth increased in response to both irrigation and $\mathbf{N}$ fertilizer $(P<0.05)$. Numbers of fruits per branch were increased by $\mathrm{N}$ fertilizer $(P<0.05)$, but were decreased by irrigation $(P<0.05)$. Stem mortality did not differ between treatments during 1984 and amounted to $42 \%$ of the mean stem length of the unirrigated, unfertilized controls.

The relationship between the length and vegetative mass of the tagged stems was described by 2 equations, 1 for unfertilized plots and 1 for fertilized:

$$
\begin{gathered}
\text { Unfertilized vegetative mass }(\mathrm{g})=2.30 \times 10^{-5} \times \text { length }(\mathrm{mm})^{2.32} \\
\text { Fertilized vegetative mass }(\mathrm{g})=2.68 \times 10^{-5} \times \text { length }(\mathrm{mm})^{2.32}
\end{gathered}
$$

The pooled $R^{2}$ from the analysis of covariance of the 2 equations was 0.76 .

Total mass increment (vegetative + fruit) per branch during spring, 1983, increased in response to $\mathrm{N}$ fertilizer in irrigated and unirrigated plots (Fig. 2). Irrigated plots without $\mathrm{N}$ fertilizer were

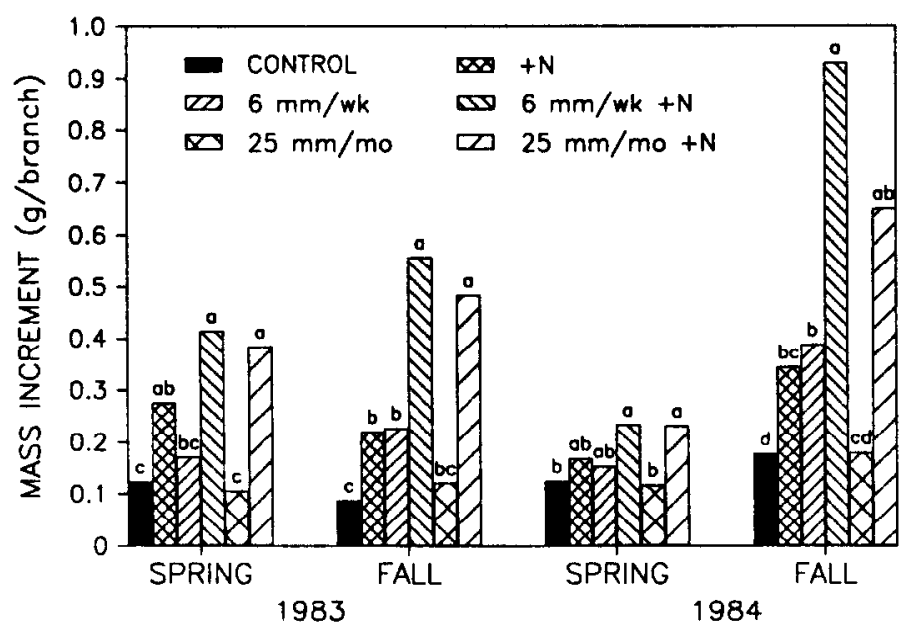

Fis. 2. Effects of nitrogen fertilization and 2 patterns of irrigation on seasonal mass increments of vegetation + fruit of tagged creosotebush branches. The spring and fall seasons correspond to before and after 1 July, respectively. Values are means of 3 plots. Significant differences (Tukey's HSD, $\mathrm{P}<0.05$ ) within a year and season are indicated by different letters.

not significantly different from controls. Total mass increment per branch in spring, 1984, showed a similar pattern across treatments except that the $\mathbf{N}$ fertilized plots without water were not significantly different from the controls. In the fall of 1983, total mass increment per branch was increased by all water and nitrogen treatments except for $25 \mathrm{~mm} \mathrm{mo}^{-1}$ water without $\mathrm{N}$. A similar pattern of total mass increment responses occurred in the fall of 1984. The principal difference between the responses of total mass increment of fall, 1983, and fall, 1984, was that the responses were higher in 1984.

Reproductive allocation was consistently higher in spring than

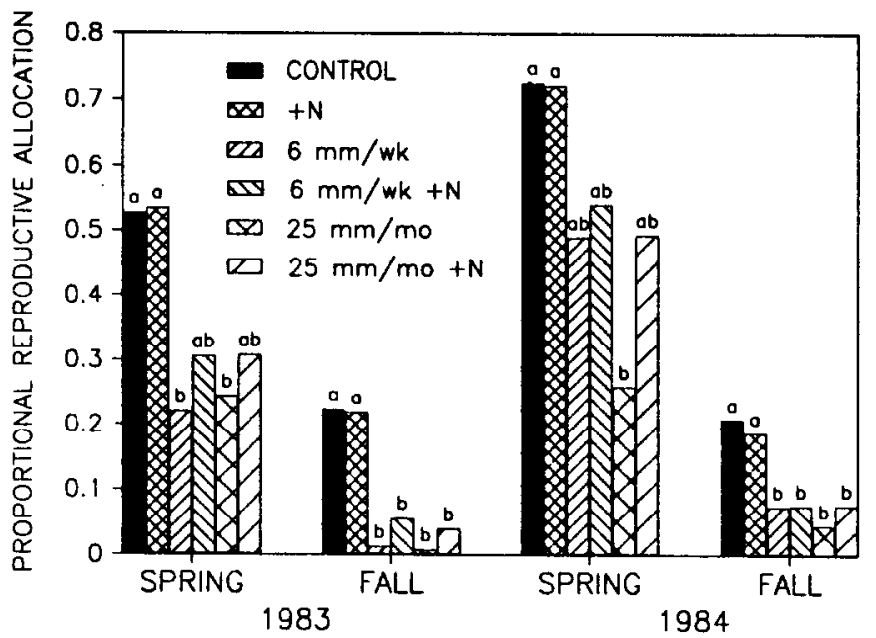

Fig. 3. Effects of nitrogen fertilization and 2 patterns of irrigation on seasonal reproductive allocation (fruit mass increment divided by the sum of vegetative + fruit mass increments). The spring and fall seasons correspond to before and after $1 \mathrm{July}$, respectively. Values are means of 3 plots. Significant differences (Tukey's $H S D, P<0.05$ ) within a year and season are indicated by different letters.

in fall across all treatments in both years (Fig. 3). In the spring of 1983 , irrigation without $\mathrm{N}$ fertilizer reduced reproductive allocation relative to the controls. $\mathbf{N}$ fertilizer tended to return reproductive allocation to control levels in the water $+\mathbf{N}$ treatments. A similar pattern of reproductive allocation across treatments occurred in the spring of 1984 except that irrigation with $6 \mathrm{~mm} \mathrm{wk}^{-1}$ without $\mathbf{N}$ fertilizer did not significantly reduce reproductive allocation below the level of the controls. In the fall of both 1983 and 1984, reproductive allocation was reduced below the controls in all irrigation treatments, even those with added $\mathrm{N}$. As with total mass increment, the major difference between years for reproductive allocation was in overall response level with similar patterns occurring across treatments in both years.

The similarity of response patterns in the 2 years led us to combine the years for further analysis. In this analysis, we used Dunnett's $t$ statistic to test for significant differences between each treatment mean and the control mean (Steel and Torrie 1980). Total mass increment in the spring was greater in all $\mathrm{N}$ fertilizer treatments than for the controls (Fig. 4). Irrigation without additional $\mathbf{N}$ had no effect on spring total mass increment. A similar pattern of responses occurred in the fall except that total mass increment was increased by irrigation with $6 \mathrm{~mm} \mathrm{wk}^{-1}$ without $\mathrm{N}$ fertilizer. Reproductive allocation in the spring decreased in response to irrigation without $\mathrm{N}$ (Fig. 4). $\mathrm{N}$ fertilizer maintained reproductive allocation at levels not significantly different from the controls. Fall reproductive allocation was also decreased by irrigation but $\mathbf{N}$ fertilization did not overcome the depressing effect of irrigation as it did in the spring.

Data from the root tubes indicated that a modest amount of root

Table 1. Growth of creosotebush roots into root tubes $(60 \mathrm{~cm}$ depth). Values are means across all treatments corrected for residual root biomass initially present in the tubes. Effects of nitrogen fertilizer and irrigation were not statistically significant $(P<0.05)$. Letters indicate significant differences between time intervals $(P<0.05)$.

\begin{tabular}{lcc}
\hline \hline Time interval & $\begin{array}{c}\text { Root biomass } \\
\left(\mathrm{g} \mathrm{m}^{-2}\right)\end{array}$ & $\begin{array}{c}\text { Root growth } \\
\left(\mathrm{g} \mathrm{m}^{-2} \mathrm{~d}^{-1}\right)\end{array}$ \\
\hline 23 Mar. 1984 to 19 June 1984 & $122 \mathrm{a}$ & $1.4 \mathrm{a}$ \\
21 June 1984 to 25 Sep. 1984 & $625 \mathrm{~b}$ & $6.5 \mathrm{~b}$ \\
30 Aug. 1984 to 10 Oct. 1984 & $475 \mathrm{~b}$ & $14.4 \mathrm{c}$ \\
\hline
\end{tabular}



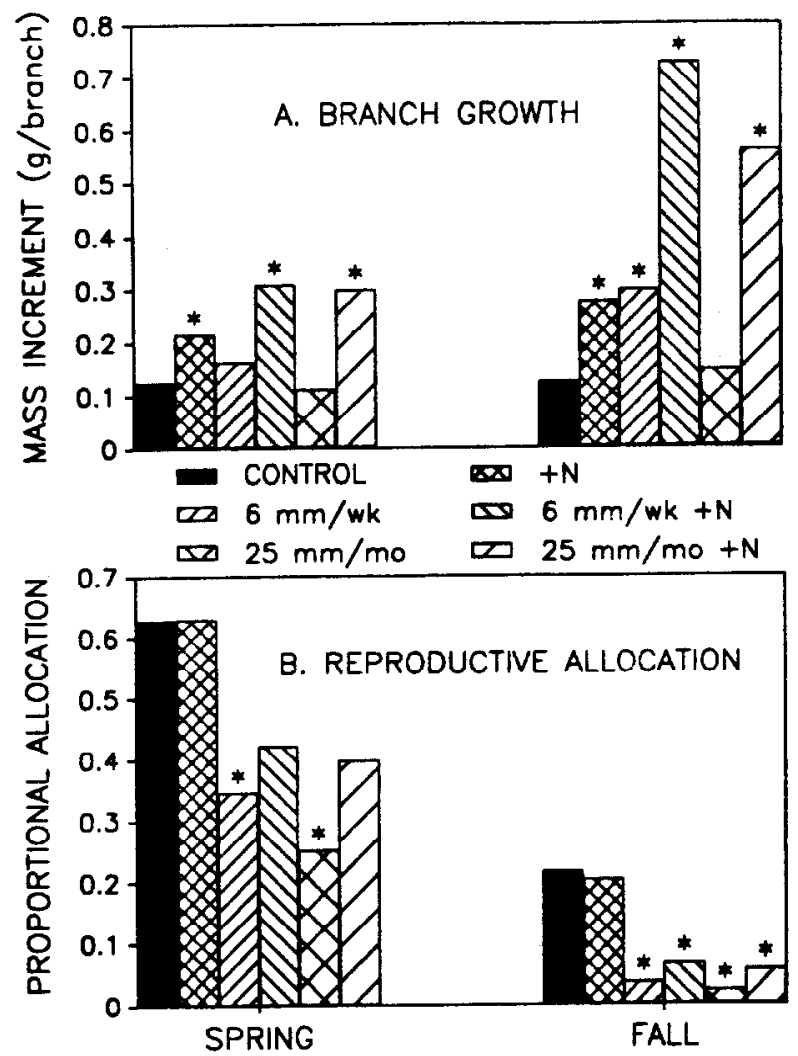

Fig. 4. Effects of nitrogen fertilization and 2 patterns of irrigation for 1983 and 1984 combined. Reproductve allocation is calculated as fruit mass increment divided by the sum of vegetative + fruit mass increments. The spring and fall seasons correspond to before and after July 1, respectively. Values are means of 3 plots. Significant differences from the control (Dunnett's $\mathrm{t}, \mathrm{P}<0.05$ ) within a season are indicated by *'.

growth occurred during the entire period of above-ground vegetative growth in 1984 . However, as with above-ground vegetative growth, most root growth occurred during the July through September period (Table 1). There were no statistically significant differences in root production among the treatments $(P<0.05)$.

\section{Discussion}

As has been observed previously in creosotebush in the Chihuahuan Desert (Cunningham et al. 1979), flowering and fruit production occurred primarily in the spring and early summer and vegetative growth primarily in late summer and autumn. This pattern persisted despite 4 years of continuous irrigation and 2 years of $N$ fertilization. Thus the phenological patterns of creosotebush appear to be controlled by photoperiod and/or temperature, not by water and nutrients.

In contrast to studies in other ecosystems (Waring and Schlesinger 1985), we found no evidence that water or $\mathrm{N}$ added individually or in combination affected the production of roots. Since additions of both water and $\mathrm{N}$ increased above-ground production, it can be concluded that both additions reduced the relative allocation of biomass to roots.

Relative allocation to reproductive effort was not affected by $\mathbf{N}$ additions alone. In contrast, water additions alone reduced reproductive allocation, confirming the results of Cunningham et al. (1979) and Oechel et al. (1972). Added N, although ineffective without added water, appears to compensate to some extent for the water-induced reduction in reproductive allocation.

Nitrogen availability limited creosotebush growth in the absence of added water, confirming a previous study in the Chihuahuan Desert (Ettershank et al. 1978). However, the response of creo- sotebush in our study to $10 \mathrm{~g}-\mathrm{N} \mathrm{m}^{-2}$ was much larger: adding $\mathrm{N}$ without water increased total above-ground mass increment by $97 \%$ vs. $24 \%$ in the previous study. The previous study was conducted in a transition zone from shrubland grassland with a significant cover of fluff grass, Erioneuron pulchellum. The response of fluff grass to added N, an increase of $100 \%$ over the controls, was similar to that of creosotebush in our study. Evidently, the shallowrooted grass successfully competed with creosotebush for the surface-applied $\mathbf{N}$.

Also confirmed was the hypothesis based on the observations of Ludwig and Flavill (1979) that small, frequent events were more effective than large, infrequent events. In fact, the large, infrequent water additions had virtually no effect on creosotebush growth in the absence of $\mathbf{N}$ fertilizer. Given the responses of creosotebush to added $\mathrm{N}$ reported in this study, and the responses of soil $\mathrm{N}$ to irrigation previously reported (Fisher et al. 1987), the simplest explanation is that the small, frequent water additions enhance $\mathbf{N}$ availability compared to large, infrequent water additions. Fisher et al. (1987) proposed that small, frequent events increase $\mathrm{N}$ mineralization by concentrating water in the surface soil layers containing most of the readily available organic $\mathrm{N}$. Frequent wetting and drying episodes occurring in the surface soil appear to promote rapid turnover of soil organic $\mathrm{N}$. Large, infrequent water additions, on contrast, allow more of the water to penetrate to deeper soil layers containing less available organic $\mathbf{N}$.

Creosotebush growth appears to be limited by both water and $\mathrm{N}$ in an interactive or synergistic manner: the combined water and $\mathrm{N}$ additions increased creosotebush growth more than the sum of the responses to the 2 resources alone. This implies that both resources are limiting (Chapin et al. 1987). Added $\mathbf{N}$ did not appear to affect the relative responses to the 2 patterns of irrigation. This is consistent with our contention that $\mathbf{N}$ availability is higher in plots receiving small, frequent water additions.

Our results suggest some of the factors that may contribute to the success of creosotebush in the northern Chihuahuan Desert. First, creosotebush appears to be well adjusted to the relative availability of water and $\mathrm{N}$ in the environment since both resources appear to limit growth. Secondly, creosotebush, despite being a deep-rooted perennial plant, is able to respond to the small precipitation events which often occur in the region. Finally, creosotebush is most responsive to increased moisture availability during the seasons of the most reliable precipitation in the northern Chihuahuan Desert, the late summer and early fall.

\section{Literature Cited}

Bufington, L.C., and C.H. Herbel. 1965. Vegetational changes on a semidesert grassland range from 1858 to 1963 . Ecol. Monogr. 35:139-164.

Chapin, F.S., III, A.J. Bloom, C.B. Field, and R.H. Waring. 1987. Plant responses to multiple environmental factors. Bioscience 37:49-57.

Charley, J.L. 1972. The role of shrubs in nutrient cycling, p. 182-203. In: C.M. McKell, J.P. Blaisdell, and J.R. Goodwin (eds), Wildland shrubs - their biology and utilization. USDA Forest Serv. Gen. Tech. Rep. INT-1, Washington, DC.

Cox, J.R., H.L. Morton, T.N. Johnsen, Jr., G.L. Jordan, S.C. Martin, and L.C. Fierro. 1984. Vegetation restoration in the Chihuahuan and Sonoran Deserts of North America. Rangelands 6:112-115.

Cunningham, G.L., J.P. Syvertsen, J.F. Reynolds, and J.M. Willson. 1979. Some effects of soil-moisture availability on above-ground production and reproductive allocation in Larrea tridentata (DC) Cov. Oecologia 40:113-123.

Ettershank, G., J.A. Ettershank, M. Bryant, and W.G. Whitford. 1978. Effects of nitrogen fertilization on primary production in a Chihuahuan Desert ecosystem. J. Arid Environ. 1:135-139.

Fisher, F.M., L.W. Parker, J.P. Anderson, and W.G. Whitford. 1987. Nitrogen mineralization in a desert soil: interacting effects of soil moisture and N fertilizer. Soil Sci. Soc. Amer. J. 51:1033-1041.

Floret, C., R. Pontanier, and S. Rambal. 1982. Measurement and modeling of primary production and water use in a south Tunisian steppe. J. Arid Environ. 5:77-90. 
Freund, R.J., and R.C. Littell. 1981. SAS for linear models. SAS Institute Inc., Cary, North Carolina.

James, D.W., and J.J. Jurinak. 1978. Nitrogen fertilization of dominant plants in the northeastern Great Basin Desert, p. 219-231. In: N.E. West and J. Skujins (eds), Nitrogen in desert ecosystems. US/IBP Synthesis Series 9. Dowdon, Hutchinson, and Ross, Stroudsburg, $\mathrm{Pa}$.

Ludwis, J.A., and P. Flavill. 1979. Productivity patterns of Larrea in the northern Chihuahuan Desert, p. 139-150. In : E.C. Lopez, T.J. Mabry, and S.F. Tavizon (eds), Larrea. Serie el Desierto, Volume 2. Centro de Investigacion en Quimica Aplicada, Saltillo, Coahuila, Mexico.

Noy-Meir, I. 1973. Desert ecosystems: environment and producers. Annu. Rev. Ecol. Sys. 5:25-51.

Oechel, W.C., B.R. Strain, and W.R. Odening. 1972. Tissue water potential, photosynthesis, ${ }^{14} \mathrm{C}$-labeled photosynthate utilization and growth in the desert shrub Larrea divaricata Cav. Ecol. Monogr. 42:127-141.

Penning de Vries, F.W.T., and M.A. Djlteye, (eds.) 1982. La productivite des paturages saheliens. Centre for Agricultural Publishing and Documentation, Wageningen, The Netherlands.
Steel, R.G.D., and J.H. Torrie. 1980. Principles and procedures of statistics, second edition. McGraw-Hill Book Co., New York.

Waring, R.H., and W.H. Schlesinger. 1985. Forest ecosystems: concepts and management. Academic Press, Orlando, Fla.

Webb, W., Szarek, S., Lauenroth, W., Kinerson, R., and M. Smith. 1978. Primary productivity and water use in native forest, grassland, and desert ecosystems. Ecology 59:1239-1247.

West, N.E., and J. Skujins. 1978. Summary, conclusions, and suggestions for further research, p. 244-253. In:2 N.E. West and J. Skujins (eds), Nitrogen in desert ecosystems. US/IBP Synthesis Series 9. Dowden, Hutchinson, and Ross, Stroudsburg, $\mathrm{Pa}$.

York, J.C., and W.A. Dick-Peddie. 1969. Vegetation changes in southern New Mexico during the past hundred years, p. 157-166. In: W.G. McGinnies and B.J. Goldman (eds), Arid lands in perspective. Univ. Arizona Press, Tucson. 